\title{
Spatial and temporal evaluation of erosion with RUSLE: a case study in an olive orchard microcatchment in Spain
}

E. V. Taguas ${ }^{1}$, P. Cuadrado ${ }^{1}$, J. L. Ayuso ${ }^{1}$, Y. Yuan ${ }^{2}$, and R. Pérez ${ }^{1}$

${ }^{1}$ University of Cordoba, Rural Engineering Department, Campus Rabanales, Leonardo Da Vinci Building, 14071, Cordoba, Spain

${ }^{2}$ USEPA/ORD/NERL/ESD, 944 East Harmon Avenue, Las Vegas, 89119, Nevada, USA

Received: 5 September 2010 - Accepted: 7 September 2010

- Published: 30 September 2010

Correspondence to: E. V. Taguas (evtaguas@uco.es)

Published by Copernicus Publications on behalf of the European Geosciences Union.

A case of spatial and temporal evaluation of erosion with

RUSLE

E. V. Taguas et al.

\section{Title Page}

Abstract

Conclusions

Tables

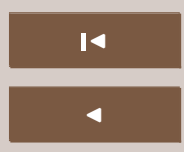

Back

Full Screen / Esc

Printer-friendly Version

Interactive Discussion 


\section{Abstract}

Soil loss is commonly estimated using the Revised Universal Soil Loss Equation (RUSLE). Since RUSLE is an empirically based soil-loss model derived from surveys on plots, the high spatial and temporal variability of erosion in Mediterranean envi5 ronments and scale effects mean that it is necessary to evaluate the model in other spatial units such as the microcatchment. In this study, a series of topographic and soil surveys was carried out on a microcatchment of 6.7 ha in a mountainous area under no-tillage farming with bare soil in order to examine spatial and temporal results produced by RUSLE. GPS measurements of the microrelief height differences were used in a control area in the microcatchment to compare observed erosion and deposition with RUSLE predictions. Erosion points located in certain areas correlate very closely with RUSLE predictions, while the distribution of deposition points showed no correlations with RUSLE predictions. Secondly, a time series of daily rainfall data was used to calculate annual erosivity values, which were fitted to an appropriate distribution function. It was determined that the rainfall distribution best fitted the Pearson type III distribution function. Next, efforts were made to quantify the long term erosion and to check the suitability of the land-use and management under different thresholds of tolerance. It was found that values of erosivity in the study area with a return period of 10 years generate a mean annual erosion of $5 \mathrm{tha}^{-1} \mathrm{yr}^{-1}$. On the study scale, RUSLE allowed us to locate the most erosive areas and to combine the suitability of the soil land-use and the management with the frequency of the annual erosivity. In addition, an annual sediment delivery ratio of approximately $47 \%$ was estimated for the period 2005-2006.

\section{Introduction}

25 Soil erosion is a serious problem in Spain, where $46 \%$ of the national territory has rates of soil loss over the tolerance values (MMA, 2007). In fact, higher erosion rates than

\section{A case of spatial and temporal evaluation of erosion with RUSLE}

E. V. Taguas et al.

\section{Title Page}

Abstract Introduction

Conclusions

References

Tables

Figures

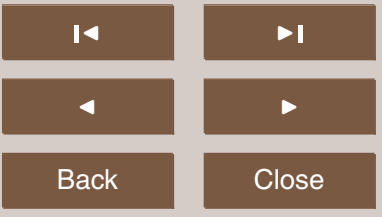

Full Screen / Esc

Printer-friendly Version

Interactive Discussion 
$50 \mathrm{tha}^{-1} \mathrm{yr}^{-1}$ can be expected in mountainous agricultural regions such as Andalusia associated to orchard crops (MMA, 2007). In this region, there are 1.48 Mha of olive orchards (CAP, 2007), which constitute a key crop in terms of income, employment and environmental impact.

5 Different studies have been conducted on small plots under a range of environmental conditions and management in order to quantify soil loss (Kosmas et al., 1997; Raglione et al., 1999; Pastor et al., 1999; Gómez et al., 2003, 2004, 2008a; De la Rosa et al., 2005; Francia et al., 2006). However, because of the high variability that characterizes the Mediterranean environments, soil erosion varies considerably over 10 space and time and in most cases, it is inappropriate to extrapolate these measures to other spatial units where different hydrological and erosive processes take place. In Andalusia, $71.4 \%$ of farmland occupies a mean size of between 2.4 ha and 18.0 ha (CAP, 2003). Thus, studies for predicting temporal and spatial distributions of soil erosion at the microcatchment scale would improve the strategies of environmental management, since not only are they carried out on real farms, but the planning of control measures also requires the cooperation of only a small number of farmers. Soil loss is commonly predicted using an empirical model such as the Universal Soil Loss Equation (USLE; Wischmeier and Smith, 1965), because of its simple structure and easy application. In Spain, both the National Map of Erosive States and the National Map of Desertification Risks have been drawn up using USLE and its revised version RUSLE (MMA, 2007). Soil erosion from an area in Spain is simply estimated as the product of empirical coefficients, originally derived from field observations in the USA. These empirical coefficients have rarely been verified against experimental and scale conditions in Spain. As a consequence, we would have to question the reliability of the results 25 when an application is carried out outside the range of calibration conditions (Amore et al., 2004).

The recent development of GPS techniques provides us with a wide range of possibilities to analyze temporal and spatial dynamics of erosion and sedimentation (Higgit and Warburton, 1999). The accuracy of GPS has been improved and it can now be

\section{A case of spatial and temporal evaluation of erosion with RUSLE}

E. V. Taguas et al.

Title Page

Abstract Introduction

Conclusions

References

Tables

Figures

14

4

Back

Close

Full Screen / Esc

Printer-friendly Version

Interactive Discussion

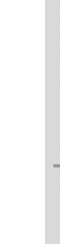


used for continuous monitoring of the small, slow morphological changes in the earth's surface (Wu and Cheng, 2005). Moreover, such equipment has become progressively more economical and easier to use in geophysical research such as: gully erosion monitoring (Wu and Cheng, 2005; Cheng et al., 2007); morphometric estimates of 5 coarse fluvial sediment transport (Brasington et al., 2003); morphological changes in slides (Malet et al., 2002); and monitoring olive tree movements caused by continuous tillage erosion (Ramos et al., 2007).

Conventional methodologies to observe soil losses were formerly based on the measurements from the top soil levels using pins or stakes as reference points (Haigh, 10 1977; Sarre, 1984). Topographic instruments such as thedolites and GPS have allowed us to improve the accuracy and maintain the use of markers that are difficult to keep in the field due to management operations (Laguna, 1989; Wessemael et al., 2006). In addition, GPS does not require a direct line of sight between the receiver and the station, which is extremely useful, considering the lack of visibility through the olive 15 trees.

A long term analysis of the temporal context is essential in order to take informed environmental decisions. Renschler et al. (1999) used an approach to examine the temporal variability of the soil loss ratios through probabilistic analysis of the quantiles of daily erosivity values under different agricultural crop rotations in basins in Andalusia 20 (southern Spain). In this study, this approach was used in order to evaluate the impact of soil management on annual erosion rates at a microcatchment scale. Therefore, the overall objectives of this study were: (1) to evaluate the spatial variability of the USLE/RUSLE estimations using GPS topographical measurements taken over a period of two years from a control area in an olive orchard microcatchment and rainfall, 25 runoff, sediment monitoring and modeling data at the outlet of the microcatchment; (2) to evaluate the long-term spatial and temporal soil losses in the catchment after the model performance was examined by exploring a simple method based on the quantile estimation of erosion.

\section{SED}

2, 275-306, 2010

\section{A case of spatial and temporal evaluation of erosion with RUSLE}

E. V. Taguas et al.

Title Page

Abstract Introduction

Conclusions

References

Tables

Figures

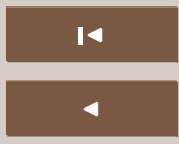

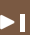

Back

Close

Full Screen / Esc

Printer-friendly Version

Interactive Discussion 


\section{Material and methods}

\subsection{Study site}

SED

The Setenil microcatchment is situated in the province of Cadiz, Spain $\left(36.88^{\circ} \mathrm{N}\right.$, $5.13^{\circ} \mathrm{W}$ ). The drainage area is $6.7 \mathrm{ha}$ (Fig. 1), with a mean elevation of $782 \mathrm{~m}$ and 5 mean slope of $10.3 \%$.

The type of climate is Mediterranean with Atlantic influences. The orographic effects influence the rainfall spatial variability so that the annual mean values in gauges about $20 \mathrm{~km}$ apart vary from $600 \mathrm{~mm}$ to $1100 \mathrm{~mm}$ (Castillo, 2002). The hottest month is July (average temperature $25 .{ }^{\circ} \mathrm{C}$ ) and the coldest January $\left(7.1^{\circ} \mathrm{C}\right)$.

10 The soil type in the catchments is Luvisol (FAO classification) with an average depth of about $1.5 \mathrm{~m}$. The soil texture is loamy sand and the average surface soil organic matter content is $0.9 \%$. In the microcatchment, there are two well-differentiated areas: the highest zone (1.4 ha) is an old area planted with cereals, with young olive trees; the rest is occupied by 20 -year-old olive trees spaced at $7 \times 7 \mathrm{~m}$ apart (Fig. 1). "Conventional tillage" has been the soil management commonly applied; however, the annual tillage operations have been reduced progressively. For the study period, no tillage operations were implemented in the area with the older olive trees although two weed controls were carried out per year in October and in March using herbicides around every tree in the rows. In contrast, tillage operations were applied in April and May 2004 to improve the growth of the young olive trees. .

\subsection{Soil erosion measures}

\subsubsection{GPS surveys: control points to observe erosion and deposition processes}

The topographical analysis was carried out only on the area with older olive trees (study

$2,275-306,2010$

\section{A case of spatial and temporal evaluation of erosion with RUSLE}

E. V. Taguas et al.

\section{Title Page}

Abstract

Conclusions

Tables

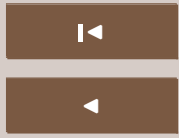

Back

Full Screen / Esc

Printer-friendly Version

Interactive Discussion 
control grid with 483 points (Fig. 2), was set up in the study area, where two topographic surveys were carried out for September 2004 and September 2005. These were made with a Leyca 1200 GPS system with a planimetric and altimetric precision of $1 \mathrm{~cm} \pm 2 \mathrm{ppm}$ and $2 \mathrm{~cm} \pm 2 \mathrm{ppm}$ expressed as root square mean error (RSME). 5 Thus, the probability for the altimetric measurements to show an error greater than $2 \mathrm{~cm}$ (RSME) was $67 \%$. The error theory in the sum of two magnitudes verifies that its error is the sum of errors of both magnitudes. Therefore, the square of the root square mean error, corresponding to the sum $\sigma_{s}$ of two magnitudes $\left(A_{\mathrm{s}}\right.$ and $\left.B_{\mathrm{s}}\right)$, when the measurements were unbiased and not correlated, will be equal to the sum of the root square mean errors of $A_{\mathrm{s}}$ and $B_{\mathrm{s}}$, defined as $a_{\mathrm{s}}$ and $b_{\mathrm{s}}$, respectively (Eq. 1).

$\sigma_{s}=\longdiv { 1 a _ { \mathrm { s } } ^ { 2 } + b _ { \mathrm { s } } ^ { 2 } }$

If $A_{\mathrm{s}}$ represents the topographic measurements in 2004 and $B_{\mathrm{s}}$ in 2005, Eq. (1) indicates that the RMSE of the altimetric differences (with a confidence level of $67 \%$ ) is $2.8 \mathrm{~cm}$. If the error is $4.0 \mathrm{~cm}$, the level of confidence rises to $84 \%$, according to Gauss 15 distribution of errors. Thus, when topographic differences $\left(B_{\mathrm{s}}-A_{\mathrm{s}}\right)$ are greater than $4 \mathrm{~cm}$ or less than $4 \mathrm{~cm}$, we will have a margin of accuracy of over $80 \%$ in order to efficiently characterize areas where the deposition and erosion are the dominant phenomena. In addition, the measurements were taken on a $1 \mathrm{~m}$ grid to include the whole area, with a tree spacing of $7 \mathrm{~m}$.

\subsubsection{Rainfall, runoff and sediment load}

In April 2005, a gauging station was built at the outlet of the microcatchments to monitor rainfall, runoff and sediment concentration data. The rainfall was measured with one gauge (Hobo Event 7852M), and the discharge was obtained by flumes of critical flow depth (Clemmens et al., 2001), where the water level was measured by an ultrasonic sensor (Milltronics Ultrasonics). When the water level rises to a determined level, the automatic sampler (ISCO $3700 \mathrm{C}$ ) turns on and fills a bottle at $10 \mathrm{~min}$ intervals. 280
SED

2, 275-306, 2010

\section{A case of spatial and temporal evaluation of erosion with RUSLE}

E. V. Taguas et al.

Title Page

Abstract Introduction

Conclusions

References

Tables

Figures

14

$\Delta$

4

Back

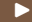

Close

Full Screen / Esc

Printer-friendly Version

Interactive Discussion 
However, the period of data acquisition (from April 2005 to April 2007) was interrupted for 83 days due to equipment malfunction. The AnnAGNPS model (Bingner and Theurer, 2003) was calibrated and validated using 22 events, and was then used to calculate the missing records for those 83 days (Taguas et al., 2009). Thus, a 5 complete data set of total sediment loads from April 2005 to April 2007 was obtained through monitoring and AnnAGNPS modelling (Taguas et al., 2009). These soil loss values and its mean value were used for examination of RUSLE predictions and the annual sediment delivery ratio (SDR) in the catchment.

\subsection{RUSLE}

10 RUSLE (Renard et al., 1997) was conceived to predict long-term average annual soil loss $(A)$ as the product of six parameters:

$A=R . K . L S . C . P$

where $A$ is computed in $\mathrm{tha}^{-1} \mathrm{yr}^{-1} ; R$ is the rainfall erosivity factor (MJ mm ha $\mathrm{ma}^{-1}$ $\mathrm{h}^{-1} \mathrm{yr}^{-1}$ ); $K$ represents the soil erodibility (tha $\mathrm{h} \mathrm{ha}^{-1} \mathrm{MJ}^{-1} \mathrm{~mm}^{-1}$ ); $L$ is the slope length 15 factor and $S$ is the slope gradient factor (dimensionless); $C$ is a cover management factor (dimensionless) and $P$ is a support practice factor (dimensionless).

\subsubsection{Slope length factor, $L S$}

$L S$ values were delineated from the DEMs derived from GPS surveys (cell size $10 \mathrm{~m}$ ) using the Arc Map Raster Calculator tools (ESRI, 2002) according to Eqs. (2) and (3):

$$
\begin{aligned}
& L S=\left(\frac{\lambda}{22.1}\right)^{0.3} \times\left(0.065+0.0454 \times S+0.0065 \times S^{2}\right) \text { if } S>9 \% \\
& L S=\left(\frac{\lambda}{22.1}\right)^{0.3} \times\left(\frac{S}{9}\right)^{1.3} \text { if } S<9 \%
\end{aligned}
$$

\section{SED}

2, 275-306, 2010

\section{A case of spatial and temporal evaluation of erosion with RUSLE}

E. V. Taguas et al.

\section{Title Page}

Abstract

Introduction

Conclusions

References

Tables

Figures

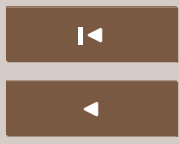

$>1$

Back

Close

Full Screen / Esc

Printer-friendly Version

Interactive Discussion 
where $S$ is the slope (\%) and $\lambda$ is the length of the slope $(\mathrm{m})$, obtained from the computation of the grid of accumulated areas ("flowaccumulation") with ARCGIS 9.2 Hydro Tools (ESRI, 2002), multiplied by the cell size (10 m).

\subsubsection{Rainfall erosivity, $R$}

5 The erosivity for the period September 2004-September 2006, corresponding to the analysis interval of the topography, was calculated using the relationships estimated by Domínguez-Romero et al. (2007) for the daily erosivity $\left(E_{\mathrm{d}}\right)$ in the province of Cadiz (Eq. 3). The catchment was equipped with a rainfall gauge in April 2005. Thus, the observed daily rainfall and available rainfall data from the nearest meteorological station 10 in Olvera $\left(5^{\circ} 15^{\prime} 31^{\prime \prime} \mathrm{W}, 36^{\circ} 55^{\prime} 59^{\prime \prime} \mathrm{N}\right.$, DGAP - Junta de Andalucía) were used, which were well-correlated $(r=0.86)$ with observed rainfall. In addition, the El values derived from Eq. (3) for the collected events (April 2005-April 2007) showed a correlation coefficient of 0.70 with the EI-RUSLE values calculated from the events with rainfall depth over $10 \mathrm{~mm}$ and at least $6 \mathrm{~h}$ apart.

${ }_{15} E_{\mathrm{d}}=0.1449 \times P^{1.8967}$

Constant grids with the annual values of erosivity were created using Arc Catalog (ARCGIS 9.2.; ESRI, 2002)

In addition, the long term daily rainfall record for Setenil $\left(5^{\circ} 10^{\prime} 57^{\prime \prime} \mathrm{W}, 36^{\circ} 51^{\prime} 51^{\prime \prime} \mathrm{N}\right.$; National Meteorological Institute, series 1950-1999) was obtained in order to examine the temporal variation of the erosivity (the rates of soil loss). Since a complete rainfall record is only available for 8 of these years, an additional analysis was performed to check if years with missing records in July and August could be included. Rainfall depth of less than $10 \mathrm{~mm}$ was usually excluded for the calculation of annual erosivity. In this way, all available July and August rainfall data was analyzed. It was found that only one rainfall event greater than $10 \mathrm{~mm}$ occurred in $13.3 \%$ of the months of July in the data series. In August, two events with a rainfall depth of over $10 \mathrm{~mm}$ occurred in $6.9 \%$ of the years and at least one event over $10 \mathrm{~mm}$ occurred in $37.9 \%$ of the months of August. 282
SED

$2,275-306,2010$

\section{A case of spatial and temporal evaluation of erosion with RUSLE}

E. V. Taguas et al.

Title Page

Abstract Introduction

Conclusions

References

Tables

Figures

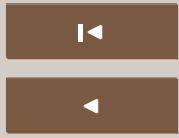

$\Delta$

Back

Close

Full Screen / Esc

Printer-friendly Version

Interactive Discussion 
This analysis justified the inclusion of years with missing July and August records. This way, we were able to use a 14-year record in Setenil station.

\subsubsection{Soil erodibility, $K$}

Soil samples were collected and surveys were conducted in July and August of 2004

5 to estimate soil properties such as texture (Robinson pippete; SCS, 1972), organic matter (Walkley-Black methodology; Nelson and Sommers, 1982), saturated hydraulic conductivity (Philip, 1993) and bulk density (Mass/Volume of clods with wax to measure their submerged weight). The structure was evaluated in the field by examining 4 profiles. The locations where the samples were collected were recorded with a GPS unit.

10 Approximately 2-5 samples/ha were randomly taken from the hillslopes of the catchment ( $n=12$ for texture and organic matter content and $n=30$ for saturated hydraulic conductivity and bulk density) to take the maximum variability according to visual characteristics such as colour, structure, tree size and surface coarse elements. Maps or grids of soil attributes were made through the interpolation of collected point values, 15 following the Inverse Distance Weighted (IDW) methodology with ARCGIS 9.2 Spatial Analyst (ESRI, 2002). Finally, the tool Raster Calculator allowed us to compute the soil erodibility map using the following equation from the RUSLE manual (Eq. 4; Renard et al., 1997):

$K=\left(2.71 \times 10^{-4}\right) \times(12-a) \times M^{1.14}+4.20 \times(b-2)+3.23 \times(c-3) / 100$

20 where $M=(100-\%$ clay $) .(\%$ silt +\%(fine sand)); $a=$ organic matter content $(\%)$; $b=$ representative code of the soil structure type (dimensionless), and $c=$ code of the soil profile permeability (dimensionless).

\subsection{Cover and support practice factors, $C$ and $P$}

The $C$ factor is dependent on previous land use, canopy and surface cover, surface roughness and soil moisture (Renard et al., 1997). A value for $C$ equal to 0.41 was 283
$2,275-306,2010$

\section{A case of spatial and \\ temporal evaluation \\ of erosion with \\ RUSLE}

E. V. Taguas et al.

Title Page

Abstract

Introduction

Conclusions

References

Tables

Figures

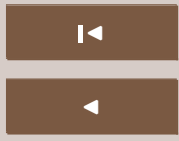

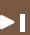

Back

Close

Full Screen / Esc

Printer-friendly Version

Interactive Discussion 
determined by Giraldez et al. (1989) and Gómez et al. (2003) for olive orchard plots under non tillage in another comparable location in Andalusia. In these works, the values of the rainfall erosivity were calculated considering the equation type of Eq. (3) $\left(E I=a \cdot P^{b}\right.$ where $\mathrm{El}$ is the daily erosivity $\left(\mathrm{MJ} \mathrm{mm} \mathrm{ha} \mathrm{m}^{-1} \mathrm{~h}^{-1}\right), P$ is the daily rainfall $(\mathrm{mm})$ 5 and $a, b$ are numerical parameters) since data series with a shorter duration than daily data are usually scarce in the region. Finally, the management factor was not considered since there are no support practices in the catchment $(P=1)$.

\subsection{Statistical analysis}

\subsubsection{Spatial exam of RUSLE-predictions and the erosion/deposition areas}

10 Firstly, erosion maps generated by the RUSLE application were examined to characterize spatial variability of the potential erosion in the hillslopes. Secondly, the RUSLE values at points where soil loss and deposition are evident processes - elevation differences of $\leq-4.0 \mathrm{~cm}$ in the case of erosion and elevation differences of $\geq+4.0 \mathrm{~cm}$ in the case of deposition - were checked to evaluate the model results. The histograms of the RUSLE predictions, the erosion/deposition measured at the grid points, and the edaphological and topographical features statistics were compared.

\subsubsection{Long term evaluation of soil erosion}

Annual values of erosivity were calculated from the data series from the Setenil station $\left(5^{\circ} 10^{\prime} 57^{\prime \prime} \mathrm{W}, 36^{\circ} 51^{\prime} 51^{\prime \prime} \mathrm{N}\right.$; National Meteorological Institute, series 1950-1999). A simple exploratory analysis was carried out, examining the statistics and the type of distribution. Equation (5) shows the conventional equation that relates the return period $(T)$ or recurrence interval with a hydrological quantile (usually rainfall depth or flow; Chow et al., 1988). Although this expression is commonly used for the design of hydrological systems, it can be used to compute any parameters related to rainfall storms, such as the rainfall erosivity (Wischmeier, 1962):
SED

2, 275-306, 2010

\section{A case of spatial and temporal evaluation of erosion with RUSLE}

E. V. Taguas et al.

Title Page

Abstract Introduction

Conclusions

References

Tables

Figures

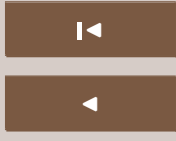

$>1$

Back

Close

Full Screen / Esc

Printer-friendly Version

Interactive Discussion 
$T=\frac{1}{1-F(X)}$

SED

where $F(X)$ is the accumulated function of probability/frequency and $X$ is the hydrological quantile, in this case, annual erosivity $(R)$.

The exceedance probability or accumulated frequency $P\left(x<x_{i}\right)$ for the series of ero5 sivity was calculated through Weibull's equation (Eq. 6; $a=0$ ) and Gringorten's equation (Eq. 6; $a=0.44)$.

$P\left(x \leq x_{i}\right)=\frac{m-a}{n+1-2 a}$

where $m$ is the order or place of the value $x_{\mathrm{i}}$ and $n$ is the total amount of data.

These values were used to adjust the continuous functions of Gumbel's (Eq. 7) and

10 Pearson's type III (Eq. 8) that supported the best fits (Abramowitz and Stegun, 1965). Kolmogorov's test (with a 5\% significance level) allowed us to check that the selected type of distributions were suitable to the values of probability.

$F(x)=P(X \leq x)=\mathrm{e}^{-\mathrm{e}^{-\alpha(x-\beta)}}-\infty \leq x \leq \infty$

$F(x)=P(X \leq x)=\frac{1}{\alpha \Gamma(\beta)} \int_{\gamma}^{x} \mathrm{e}^{-\left(\frac{x-\gamma}{\alpha}\right)}\left[\frac{x-\gamma}{\alpha}\right]^{\beta-1} d x$

15 where $\alpha, \beta, \gamma$ are the form parameters of the distributions and $\Gamma(\beta)$ is a gamma function.

Finally, the correlation coefficient of observed-adjusted values $(R)$ and the root mean square error (RSME) were evaluated to justify the best fit, obtaining the quantiles of the annual erosivity for different return periods (2, 5, 10 and 15 years). These quantiles were used to calculate potential erosion and to assess the land-use and the management practices in the catchment according to the temporal variability of rainfall.

\section{A case of spatial and temporal evaluation of erosion with RUSLE}

E. V. Taguas et al.

\section{Title Page}

Abstract

Introduction

Conclusions

References

Tables

Figures

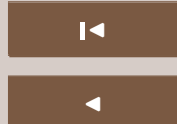

$>1$

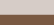

Back

Close

Full Screen / Esc

Printer-friendly Version

Interactive Discussion 


\section{Results}

\subsection{Spatial evaluation of soil erosion}

Table 1 shows a summary of the values of erosion for both study periods. As can be seen, the $R$-value for the period 2004-2005 was $340.4 \mathrm{MJ} \mathrm{mm} \mathrm{ha}^{-1} \mathrm{~h}^{-1} \mathrm{yr}^{-1}$ while

$5733.9 \mathrm{MJ} \mathrm{mm} \mathrm{ha}^{-1} \mathrm{~h}^{-1} \mathrm{yr}^{-1}$ was calculated for the 2005-2006 campaign. The annual rainfall was $279 \mathrm{~mm}$ and $553 \mathrm{~mm}$, respectively. LS-factor distributions obtained from both topographic surveys were very close, although lower values were calculated for the 2005-2006 period. The spatial mean value of $K$-factor was $0.030 \mathrm{th} \mathrm{MJ}^{-1} \mathrm{~mm}^{-1}$, with a variation coefficient of $23.3 \%$ (Table 1). As a result, the annual erosion for to the period 2004-2005 was 1.5 tha $\mathrm{yr}^{-1}$, while $3.2 \mathrm{tha}^{-1} \mathrm{yr}^{-1}$ was calculated for the 2005-2006 period. Extreme values were found next to the channel, as a result of the maximum values of $L S$-factor, while higher areas half-way up the hillslope showed the lowest values of erosion (Fig. 2a-b).

Figure 2 shows the distribution of erosion and deposition, according to the differences of height (between the 2004-2005 measurement periods) in the 483 control points, with a confidence level of over 80$\}$. As can be seen, out of 483 control points, only 30 points were considered as places with evident soil losses, compared with 56 points in the case of deposition. Erosion points were mainly located in rills areas situated half-way up hillslopes and near the stream in areas with higher $K$-factor and LS-factor, while deposition points were concentrated next to the outlet and the edge of the field where $K$-factor is generally lower and $L S$-factor is higher (Table 2, Fig. 3a). Soil properties and topographical features at erosion and deposition points contribute to explaining these tendencies (Table 3 ). Thus, the deposition points were situated in areas with higher values of saturated hydraulic conductivity $(19.7 \mathrm{~cm} / \mathrm{h})$ than the aver-

age in the study area $(15 \mathrm{~cm} / \mathrm{h})$, while erosion points tended to be found in areas with

higher slopes $\left(6.8^{\circ}\right.$ versus $\left.6.4^{\circ}\right)$ and bulk density $\left(1.69\right.$ versus $\left.1.66 \mathrm{~g} / \mathrm{cm}^{3}\right)$ and lower values of saturated hydraulic conductivity $(13.5 \mathrm{~cm} / \mathrm{h})$. In Fig. $4 \mathrm{a}$, we can observe how the distribution of erosion points is concentrated in the range of saturated hydraulic

\section{A case of spatial and temporal evaluation of erosion with RUSLE}

E. V. Taguas et al.

\section{Title Page}

Abstract Introduction

Conclusions

References

Tables

Figures

14

$\rightarrow 1$

4

Back

Close

Full Screen / Esc

Printer-friendly Version

Interactive Discussion 
conductivity between 0 and $15 \mathrm{~cm} / \mathrm{h}$, where we find $75.0 \%$ of the points. In contrast, into the interval $0-15 \mathrm{~cm} / \mathrm{h}$ we find $58.9 \%$ of the study area points. In the case of local slope (Fig. 4 a, below), we can observe a similar tendency, since $55.6 \%$ of the erosion points were located on the slopes higher than $8^{\circ}$ while in the study area, $40.9 \%$ of the 5 points are situated on this slope interval. Bimodal distributions could indicate the different patterns or combinations of factors involved in the generation of erosion. On the other hand, $50.0 \%$ of the deposition points (Fig. $4 \mathrm{~b}$ ) showed larger saturated hydraulic conductivity than the mean (equal to $19.7 \mathrm{~cm} / \mathrm{h}$ ), while only $31.2 \%$ of the study area points exceded this value.

10 In addition, the histogram of the RUSLE values for the erosion points and deposition points has been compared with the distribution of RUSLE predictions in the study area (Fig. 3). As can be observed in Table 2 and Fig. 5, the erosion points tended to be found in areas with an erosion range between 1.5 and 5 tha/year, which explains the higher mean value of soil losses at erosion points. In the case of deposition, both histograms presented a similar distribution of intervals. Finally, the sediment load calculated in the catchment for the period September 2005-September 2006 was $1.1 \mathrm{Mg} \mathrm{ha}^{-1}$ (Taguas et al., 2009), which means an annual sediment delivery ratio for the whole catchment of $47.2 \%$.

\subsection{Assessment of the suitability of the management in terms of the temporal variation of rainfall}

Table 4 shows the results of adjusting tests of accumulating distribution functions. Although the discordance value $(D)$ calculated for Kolmogorov-Smirnoff's test was lower than in the statistics $K$ (significance level =5\%) for all cases, the exceedance probability values calculated by Gringorten's equation and the fit for the Pearson Type III 25 function provided the best adjustment with an RMSE of $102.5 \mathrm{MJ} \mathrm{mm} \mathrm{ha}^{-1} \mathrm{~h}^{-1}$ and a correlation coefficient between the observed and estimated values $(R)$ of 0.98 .

Finally, Table 5 shows the quantiles of $R$ for the return periods 2, 5, 10 and 15 years and the corresponding values of potential erosion. The values of potential erosion

\section{A case of spatial and temporal evaluation of erosion with RUSLE}

E. V. Taguas et al.

\section{Title Page}

Abstract Introduction

Conclusions

References

Tables

Figures

14

4

Back

Close

Full Screen / Esc

Printer-friendly Version

Interactive Discussion

(0)

.


showed differences of $300 \%$ from the quantile of 2 years of return period to the quantile of 15 years return period. As can be observed, the annual erosivity with the recurrence period of 10 years (equivalent to an accumulated frequency of 0.9 ) implies soil losses of over $5 \mathrm{tha}^{-1} \mathrm{yr}^{-1}$ and soil losses of over $10 \mathrm{t} /$ ha yr in $10 \%$ of the area (Fig. 6b).

\section{Discussion}

The annual erosion rates provided by RUSLE are comparable to soil losses observed in the catchment and rates given by other authors under the same land-use and management. Gómez et al. (2008c), in a small catchment (8 ha) with olive trees under conventional tillage, recorded an annual sediment delivery ratio of $17 \%$ and mean soil 10 losses of $4.3 \mathrm{tha}^{-1} \mathrm{yr}^{1}$. The calculated annual sediment delivery ratio for the whole catchment was equal to $47.2 \%$. Authors such as Schoorl and Vedkamp (2001) estimated a sediment delivery ratio of about $90 \%$, and soil loss of $3 \mathrm{tha}^{-1} \mathrm{yr}^{-1}$ for an olive orchard by applying the LAPSUS model (Schoorl et al., 2002). As a result of the wide variation of the hydrological features for the measurement periods, substantial temporal differences of sediment delivery ratio could be expected.

Amore at al. (2004) also concluded that different experimental conditions (plot or field areas), which were originally used to develop models such as WEPP and USLE, were suitable for estimating the eroded soils. However, slightly higher mean values equal to $5 \mathrm{tha}^{-1} \mathrm{yr}^{-1}, 8.5 \mathrm{tha}^{-1} \mathrm{yr}^{-1}$ and $20 \mathrm{tha}^{-1} \mathrm{yr}^{-1}$ were provided by Pastor et al. (2001), 20 Francia et al. (2006) and Gómez et al. (2008a), respectively, in olive orchard plots under no tillage. Besides the differences in hydrological conditions, these variations must be related to scale effects and sediment redistribution.

$10 \times 10 \mathrm{~m}$ regular grid was choosen to examine different zones in the catchment given due to the $7 \times 7 \mathrm{~m}$ olive tree spacing while the selected height threshold of number and the type of samplers do not allow the absolute quantitative evaluation of RUSLE predictions (especially in inter-rill erosion) due to the limitations of current

SED

2, 275-306, 2010

\section{A case of spatial and temporal evaluation of erosion with RUSLE}

E. V. Taguas et al.

Title Page

Abstract Introduction

Conclusions

References

Tables

Figures

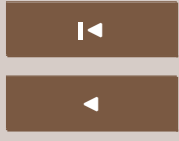

$\Delta$

Back

Close

Full Screen / Esc

Printer-friendly Version

Interactive Discussion

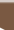

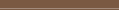


GPSs measurements. However, the spatial variability of RUSLE estimations could be evaluated and it was found that the highest values of erosion derived from RUSLE were located at measurement points with evident soil losses. Erosion points were mainly found in places with the highest length-slope and the lowest infiltration. Deposi5 tion points from the survey were not verified from RUSLE predictions because RUSLE does not account for deposition (Wishemeier, 1976). However, it was found that the distribution of deposition points responded mainly to the highest values of saturated hydraulic conductivity in the catchment. Topographical features, such as drainage area and slope, did not reveal a clear tendency. In addition, bimodal distributions of the slope 10 and saturated hydraulic conductivity indicate different combinations of topographical and edaphological properties in the processes of erosion/deposition in the catchment. This could be explained by the discontinuation of runoff generation in Mediterranean areas, where slopes behave like a patchwork for runoff, and the run-on areas are under different combinations of topographical, edaphological and land-uses properties 15 (Cerdá, 1998; Calvo-Cases et al., 2003). Bracken and Kirkby (2005) also remarked that the differences in soil infiltration can provoke non-uniform patterns of runoff generation across hillslopes, which will in turn have an impact on sediment transport.

On the other hand, the common or expected values for erosion in olive groves in the Mediterranean area has recently become a controversial issue (Fleskens and Stroosnijder, 2007; Gómez et al., 2008b). Fleskens and Stroosnijder (2007) remarked that the low frequency of intense rainfall events determines annual erosion. However, in Andalusia, the mean annual rainfall values vary from 200 to $2000 \mathrm{~mm}$ (CMA, 2009) and mean annual erosivity varies from less than 50 to $10000 \mathrm{MJ} \mathrm{mm} \mathrm{ha}^{-1} \mathrm{~h}^{-1}$ (CMA, 2009). Therefore, mean erosion rates should not be taken as an indicator of the real erosion processes (González-Hidalgo et al., 2009), and so the use of average climatic values for analyzing soil erosion is debatable (González-Hidalgo et al., 2007). The application of magnitude-frequency analogous analysis to our approach is recommended by authors such as González-Hidalgo et al. (2007) to provide a temporal context in which to obtain an accurate evaluation of erosion. These types of rainfall analysis were

\section{SED}

2, 275-306, 2010

\section{A case of spatial and temporal evaluation of erosion with RUSLE}

E. V. Taguas et al.

Title Page

Abstract Introduction

Conclusions

References

Tables

Figures

14

4

Back

Close

Printer-friendly Version

Interactive Discussion 
devised at the origin of USLE to evaluate soil loss (Wischmeier, 1962); however, their main limitation is the lack of long-term data series. In fact, in this study, data on the intensity of rainfall with a shorter duration than a day was not available. In addition, not only does the frequency analysis of the erosivity allow us to standarize the effects 5 of rainfall when we compare the suitability of land-use or soil management in different areas and design structures for soil protection (Larson et al., 1997), but it could also combine the impact of the number of rainfall days with different intensity values along the year

Soil loss per year of between $5-10 \mathrm{tha}^{-1} \mathrm{yr}^{-1}$ for a soil depth of more than $1 \mathrm{~m}$ is 10 acceptable (Schertz, 1983). However, a soil depth over $1 \mathrm{~m}$ is not usually present in the areas where the olive trees are tended. Therefore, our results indicate that a recurrence time of 5 years leads to serious soil losses, since rates over $5 \mathrm{tha}^{-1} \mathrm{yr}^{-1}$ are expected in $20 \%$ of the catchment area. The use of a cover crop is the main soil protection measure recommended (Gómez et al., 2008a), especially in areas located 15 in the middle of hillslopes with the highest slope values.

\section{Conclusions}

An analysis of the two topographic surveys conducted to analyze the height variations allowed us to carry out a spatial examination of the RUSLE predictions, which were suitable for locating the areas with the highest risk of erosion in an olive orchard microcatchment; but the surveys can not examine the deposition areas. The accuracy of current GPS devices limits the application for absolute quantitative studies of erosion, however, its application allowed the study of the local distribution of splash and rill erosion, both processes included into the analysis with RUSLE.

Although bimodal distributions of the slope and saturated hydraulic conductivity indicated different combinations of topographical and edaphological properties in the processes of erosion/deposition in the catchment, erosion points were found in places

\section{SED}

2, 275-306, 2010

\section{A case of spatial and temporal evaluation of erosion with RUSLE}

E. V. Taguas et al.

\section{Title Page}

Abstract Introduction

Conclusions

References

Tables

Figures

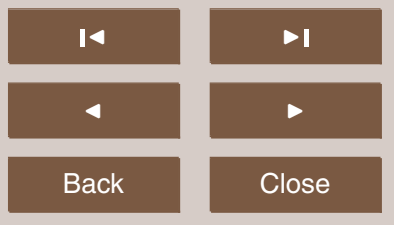

Full Screen / Esc

Printer-friendly Version

Interactive Discussion 
with the highest length-slope and the lowest infiltration while deposition points occupied mainly to the highest values of saturated hydraulic conductivity in the catchment.

The wide variation of annual rainfall, the erosivity values and the need to provide a temporal context for soil loss estimates in the Mediterranean area justify the application

5 of frequency analysis instead of the use of mean values. In this case, the exceedance probability values for the annual erosivity calculated by Gringorten's equation and the fit of the Pearson Type III function provided the best adjustment. Our results suggest that a recurrence time of 5 years could cause serious soil losses, since rates over $5 \mathrm{tha}^{-1} \mathrm{yr}^{-1}$ are expected in $20 \%$ of the catchment area.

10 Acknowledgements. This research was supported by the following Research Project: "Integration of erosive processes in olive orchards in mountainous areas in the province of Cadiz", (AGL-2002-03400), funded by the Spanish Government's Ministry of Science and Technology (Ministerio de Ciencia y Tecnología). We are very grateful to José and Alonso Zamudio, the owners of the farm who has allowed us to conduct all the surveys. We are also very grateful to

15 J. Carlos González-Hidalgo for his recommendations and the bibliography he provided.

\section{References}

Abramowitz, M., and Stegun, I. A.: Handbook of mathematical functions, Dover, New York, 1965.

Amore, E., Modica, C., Nearing, M., and Santoro, V.: Scale effect in USLE application for soil erosion computation from three Sicilian basins, J. Hydrol., 293, 100-114, 2004.

Bingner, R. L. and Theurer, F.: Agricultural non-point source pollution model, AnnAGNPS Technical Processes Documentation Version 3.3, USDA-ARS-NRCS, Oxford, MS, USA, 2003.

Bracken, L. J., and Kirkby, M.: Differences in hillslope runoff and sediment transport rates within two semi-arid catchments in southeast Spain, Geomorphology, 68, 183-200, 2005.

25 Brasington, J., Langham, J., and Rumsby, B.: Methodological sensitivity of morphometric estimates of coarse fluvial sediment transport, Geomorphology, 53, 299-316, 2003.

Calvo-Cases, A., Box-Fayos, C., and Imenson, A. C.: Runoff generation, sediment movement and soil water behaviour on calcareous (limestone) slopes of some Mediterranean environments in southeast Spain, Geomorphology, 50, 269-291, 2003.

\section{A case of spatial and temporal evaluation of erosion with RUSLE}

E. V. Taguas et al.

\section{Title Page}

Abstract Introduction

Conclusions

References

Tables

Figures

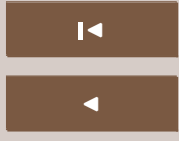

$\Delta$
Back

Close

Full Screen / Esc

Printer-friendly Version

Interactive Discussion

\section{se}

EC

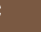

(1)


CAP - Consejería de Agricultura y Pesca: Junta de Andalucía, El olivar andaluz, Servicio de Publicaciones y Divulgación, Sevilla Spain, 2003.

CAP - Consejería de Agricultura y Pesca: Anuarios de las estadísticas agrarias y pesqueras, Años 2004-2000, Servicio de Publicaciones y Divulgación, available at: 5 http://www.juntadeandalucia.es/agriculturaypesca/portal/opencms/portal/DGPAgraria/ Estadisticas/estadisticasagrarias?entrada $=$ tematica\&tematica $=271 \&$ subtematica $=$ 760\&subsubtematica=763., Junta de Andalucía, Sevilla, Spain, 2008.

Castillo, C.: Graduation project: Diagnóstico del problema de inundaciones y propuesta de soluciones en el río Guadalpocún a su paso por Torre-Alháquime (Cádiz), Agronomy and 10 Forest Engineering School, University of Cordoba, Spain, 2002.

Cerdá, A.: The influence of geomorphological position and vegetation cover on the erosional and hydrological proceses on a Mediterranean hillslope, Hydrol. Proces., 12, 661-671, 1998.

Cheng, H., Zou, X., Wu, Y., Zhang, C., Zheng, Q., and Zhangyan, J.: Morphology parameters 15 of ephemeral gully in characteristics hill slopes on the Loess Plateau of China, Soil Till. Res., 94, 4-14, 2007.

Chow, V. T., Maidment, D. R., and Mays, L. W.: Applied Hydrology, McGraw-Hill, New York, 1988.

Clemmens, A. J., Wahl, T. L., Bos, M. G., and Replogle, J. A.: Water measurement with flumes 20 and weirs, Publication 58, International Institute for Land Reclamation and Improvements, The Netherlands, 2001.

CMA - Consejería de Medio Ambiente: Junta de Andalucía, available at: http://www.juntadeandalucia.es/medioambiente/site/ web/menuitem.a5664a214f73c3df81d8899661525ea0/?vgnextoid= 249f66ad0c378010VgnVCM1000000624e50aRCRD\&vgnextchannel= a1d9e2df6aaad110VgnVCM1000001325e50aRCRD\&Ir=lang_es, Estadística de niveles de erosividad de la lluvia en Andalucía, 2009.

De La Rosa, D., Diz-Pereira, E., Mayol, F., Czyz, E. A., Dexter, A. R., Dumitru, E., Enache, R., Fleige, H., Horn, R., Rajkay, K. Y., and Simota, C.: SIDASS Project part 2, Soil erosion as 30 a function of soil type and agricultural management in a Seville olive area, southern Spain, Soil Till. Res., 82, 19-28, 2005.

Domínguez-Romero, L., Ayuso, J. L., and García-Marín, A.: Annual distribution of rainfall erosivity in western Andalusia (southern Spain), J. Soil Water Conserv., 62(6), 390-403, 2007.

\section{A case of spatial and temporal evaluation of erosion with RUSLE}

E. V. Taguas et al.

\section{Title Page}

\section{Abstract}

Conclusions

Tables

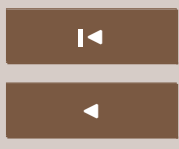

Back
Introduction

References

Figures

$\Delta$

Close
Full Screen / Esc

Printer-friendly Version

Interactive Discussion 
ESRI: Getting started with ArcGis 9, Redlands, New York, USA, 2002.

Fleskens, L. and Stroosnijder, L.: Is soil erosion in olive groves as bad as often claimed? Geoderma, 141(3-4), 260-271, 2007.

Francia, A., Durán, V., and Martínez, A.: Environmental impact of mountainous olive orchards under different soil-management systems (SE Spain), Sci. Total Environ., 358, 46-60, 2006.

Giraldez, J. V., Laguna, A., and González, P.: Soil conservation under minimum tillage techniques in Mediterranean dry farming, Soil Technol., 1, 139-147, 1989.

Gómez, J. A., Battany, M., Renschler, C. S., and Fereres, E.: Evaluating the impact of soil management on soil loss in olive orchards, Soil Use Manage., 19, 127-134, 2003.

10 Gómez, J. A., Giráldez, J. V., and Vanwalleghem, T.: Comments on "Is soil erosion in olive groves as bad as often claimed?" by L. Fleskend and L. Stroosnijder, Geoderma, 147, 9395, 2008b.

Gómez, J. A., Romero, P., Giráldez, J. V., and Fereres, E.: Experimental assessment of runoff and soil erosion in an olive grove on a Vertic soil in southern Spain affected by soil management, Soil Use Manage., 20, 426-431, 2004.

Gómez, J. A., Sobrino, T., Giráldez, J. V., and Fereres, E: Soil management effects on runoff, erosion and soil properties in an olive grove of Southern Spain, Soil Till. Res., 102, 5-13, 2009.

Gómez, J. A., Vanwalleghem, T., and Giráldez, J. V.: Preliminary results of soil erosion at different scales in an olive orchard in Southern Spain, Abstract-Meeting, European General Union Assembly 2008, EGU2008-A-03977, Vienna, Austria, 2008c.

González-Hidalgo, J. C., De Luis, M., and Batalla, R. J.: Effects of the largest daily events on total soil erosion by rainwater, An analisys of the USLE database, Earth Surf. Proc. Land., 34, 2070-2077, 2009.

González-Hidalgo, J. C., Peña-Monné, J. L., and De Luis, M.: A review of daily soil erosion in Western Mediterranean areas, Catena, 71, 193-199, 2007.

Haigh, M. J.: The use of erosion pins in the study of slope evolution, Br. Geomorph. Res. Group Tec. Bull., 29, 31-32, 1977.

Higgit, D. L., and Warbuton, J.: Applications of differential GPS in upland fluvial geomorphology, Geomorphology, 29, 121-134, 1999.

Kosmas, C., Danalatos, N., Cammeraat, L. H., Chabart, M., Diamantopoulus, J., Farand, R., Gutiérrez, L., Jacob, A., Marques, H., Martínez-Fernández, J., Mizara, A., Moustakas, N., Nicolau, J. M., Oliveiros, C., Pinna, G., Puddu, R., Puigdefábregas, J., Roxo, M., Simao, A.,

\section{A case of spatial and \\ temporal evaluation of erosion with RUSLE}

E. V. Taguas et al.

\section{Title Page}

Abstract

Introduction

Conclusions

References

Tables

Figures

14

$>1$

4

Back

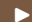

Full Screen / Esc

Printer-friendly Version

Interactive Discussion 
Stamou, G., Tomasi, N., Usai, D., and Vacca, A.: The effect of land use on runoff and soil erosion rates under Mediterranean conditions, Catena, 29, 45-59, 1997.

Laguna, A.: Análisis cuantitativo de la erosión del suelo, Ph.D. Thesis, University of Cordoba, Cordoba, Spain, 1989.

5 Larson, W. E., Lindstrom, M. J., and Schumacher, T. E.: The role of severe storms in soil erosion: a problem needing consideration, J. Soil Water Conserv., 52, 90-95, 1997.

Malet, J. P., Maquaire, O., and Calais, E.: The use of Global Positioning System techniques for continuous monitoring of landslides: application to the Super-Sauze earthflow (Alpes de Haute Provence, France), Geomorphology, 43, 33-54, 2002.

10 MMA - Ministerio De Medio Ambiente: Dirección General De Conservación De La Naturaleza, Programa de Acción Nacional contra la Desertificación, available in: http: //www.mma.es/portal/secciones/biodiversidad/desertificacion/programa_desertificacion/pdf/ PAND_dic_web_2007.pdf, 2008.

Nelson, D. W. and Sommers, L. E.: Total carbon, organic carbon, y organic matter, in: Methods of soil analysis: chemical and microbiological properties, part 2, edited by: Page, A. L., Millerr, H., and Keeney, D. R., 2nd edition, Madison, Soil Sci. Soc. Am., 539-577, 1982.

Pastor, M., Castro, J., Vega, V., and Humanes, M. D.: Sistema de manejos de suelo, in: El cultivo del olivo, edited by: Barranco, D., Fernández, R. E., and Rallo, L., Mundi Prensa, Madrid, Spain, 198-228, 1999.

Philip, J. R.: Approximate analysis of falling-head lined borehole permeameter, Water Resour. Res., 29, 3763-3768, 1993.

Ramos, M. I., Gil, A. J., Feito, F. R., and García-Ferrer, A.: Using GPS and GIS tools to monitor olive tree movements, Comput. Electron. Agr., 57, 135-148, 2007.

Renard, K. G., Foster, G. R., Wessies, G. A., Mccool, D. K., and Yoder, D. C.: Predicting Soil Erosion by Water: A Guide to Conservation Planning with the Revised Universal Loss Equation (RUSLE), USDA Agriculture Handbook, No. 703, 1997.

Renschler, C. S., Mannaerts, C., and Diekkruger, B.: Evaluating spatial and temporal variability in soil risk-rainfall erosivity and soil loss ratios in Andalucia, Spain, Catena, 34, 209-225, 1999.

30 Sarre, R. D.: A subsurface baseplate technique for monitoring small-scale changes in surface levels, Br. Geomorph. Res. Group Tec. Bull., 33, 27-32, 1984.

Schertz, D. L.: The basis for soil tolerances, J. Soil Water Conserv., 34(1), 10-14, 1983.

\section{SED}

2, 275-306, 2010

\section{A case of spatial and \\ temporal evaluation \\ of erosion with \\ RUSLE}

E. V. Taguas et al.

Title Page

\section{Abstract}

Conclusions

Tables

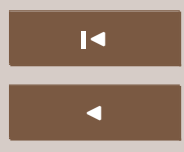

Back
Introduction

References

Figures

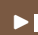

Close
Full Screen / Esc

Printer-friendly Version

Interactive Discussion 
Schoorl, J. M. and Veldkamp, A: Linking land use and landscape modelling: a case study for the Álora region (south Spain), Agr. Ecosyst. Environ., 85, 281-292, 2001.

Schoorl, J. M., Veldkamp, A., and Bouna, J.: Modelling water and soil redistribution in a dynamic landscape context, Soil Sci. Soc. Am., 66-1610-1619, 2002..

5 SCS - Soil Conservation Service: Soil Survey laboratory methods and procedures for collecting soil samples, Soil Survey Report, 1 U.S.D.A., Washington, USA, 1972.

Taguas, E. V., Peña, A., Ayuso, J. L., Yuan, Y., and Pérez, R.: Evaluating and modelling the hydrological and erosive behaviour of an olive orchard microcatchment under non tillage with bare soil in Spain, Earth Surf. Proc. Land., 34(5), 738-751, 2009.

10 Wessemael, B., Rambaud, X., Poesen, J., Muligan, M., Cammeraat, E., and Stevens, A.:Spatial patterns of land degradation and their impact on the water balance of rainfed treecrops: $A$ case study in South East Spain, Geoderma, 133, 43-56, 2006.

Wischmeier, W. H.: Storms and soil conservation, J. Soil Water Conserv., 17, 55-59, 1962.

Wischmeier, W. H.: Use and misuse of the universal loss equation, J. Soil Water Conserv., 31(1), 5-9, 1976.

Wischmeier, W. H., and Smith, D. D.: Predicting rainfall-erosion losses from cropland east of the Rocky Mountains: guide for selection of practices for soil and water conservation, US Department Agricultural Handbook no. 282, Washington, DC, 47 p., 1965.

$\mathrm{Wu}, \mathrm{Y}$. and Cheng, H.: Monitoring of gully erosion on the Loess Plateau of China using a global positioning system, 2005, Catena, 63, 154-166, 2005.

SED

$2,275-306,2010$

\section{A case of spatial and \\ temporal evaluation \\ of erosion with \\ RUSLE}

E. V. Taguas et al.

\section{Title Page}

Abstract

Introduction

Conclusions

References

Tables

Figures

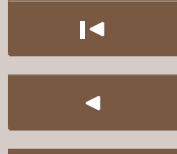

$>1$

Back

Close

Full Screen / Esc

Printer-friendly Version

Interactive Discussion 
$2,275-306,2010$

\section{A case of spatial and temporal evaluation of erosion with RUSLE}

Table 1. Rates of erosion and values of $R$-factor, $L S$-factor and $K$-factor in the study area for the periods 2004-2005 and 2005-2006.

\begin{tabular}{lrrrcccc}
\hline & \multicolumn{2}{c}{ Erosion $\left(\mathrm{tha}^{-1} \mathrm{y}^{-1}\right)$} & \multicolumn{2}{c}{$R$ - factor $\left(\mathrm{MJ} \mathrm{mm} \mathrm{ha}^{-1} \mathrm{~h}^{-1}\right)$} & \multicolumn{2}{c}{$L S$-factor } & \multicolumn{2}{c}{$K$-factor } \\
& 2004-2005 & 2005-2006 & 2004-2005 & 2005-2006 & 2004-2005 & 2005-2006 & $\left(\mathrm{th} \mathrm{MJ}^{-1} \mathrm{~mm}^{-1}\right)$ \\
\hline M & 1.47 & 3.17 & 340.4 & 733.9 & 0.32 & 0.17 & 0.030 \\
Dv & 1.55 & 3.28 & - & - & 0.30 & 0.26 & 0.004 \\
Min & 0.00 & 0.00 & - & - & 0.00 & 0.00 & 0.016 \\
Max & 10.20 & 22.10 & - & - & 2.04 & 2.18 & 0.038 \\
\hline
\end{tabular}

Title Page

Abstract Introduction

Conclusions

References

Tables

Figures

14

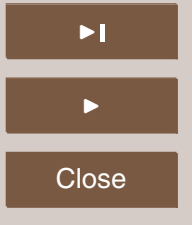

Back

Full Screen / Esc

Printer-friendly Version

Interactive Discussion 
$2,275-306,2010$

Table 2. Statistics of $K$-factor, LS-factor (period 2004-2005) and rates of erosion (period 20042005) for the erosion points, depositon points and for the study area $(M=$ mean; $D v=$ standard deviation; Max = maximum; Min = minimum).

\begin{tabular}{lllll}
\hline & Sta. & Study area & Erosion points & Deposition points \\
\hline K-Factor $\left(\mathrm{th} \mathrm{MJ}^{-1} \mathrm{~mm}^{-1}\right.$ ) & $\mathrm{M}$ & 0.030 & 0.032 & 0.027 \\
& Dv & 0.004 & 0.002 & 0.004 \\
& Max & 0.038 & 0.035 & 0.033 \\
& Min & 0.016 & 0.027 & 0.017 \\
LS-Factor & $\mathrm{M}$ & 0.32 & 0.38 & 0.36 \\
& Dv & 0.30 & 0.49 & 0.35 \\
& Max & 2.04 & 1.91 & 1.58 \\
RUSLE estimates $\left(\mathrm{tha}^{-1} \mathrm{y}^{-1}\right)$ & Min & 0.0 & 0.00 & 0.00 \\
& $\mathrm{M}$ & 1.47 & 1.81 & 1.56 \\
& Dv & 1.55 & 1.65 & 1.86 \\
& Max & 10.20 & 8.57 & 8.30 \\
& Min & 0.00 & 0.22 & 0.00 \\
\hline
\end{tabular}

\section{A case of spatial and temporal evaluation of erosion with RUSLE}

E. V. Taguas et al.

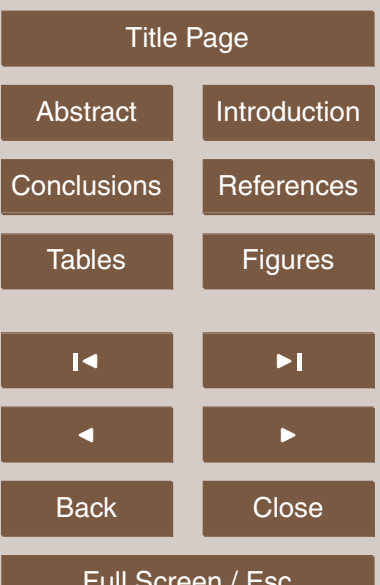

Printer-friendly Version

Interactive Discussion 
Table 3. Statistics of drainage area $(A)$, local slope $(\beta)$, saturated hydraulic conductivity $\left(K_{\text {sat }}\right)$ and bulk density (BD) (period 2004-2005) for the erosion points, depositon points and for the study area $(\mathrm{M}=$ mean; $\mathrm{Dv}=$ standard deviation; $\mathrm{Max}=$ maximum; $\mathrm{Min}=$ minimum $)$.

\begin{tabular}{llrrr}
\hline Attribute & Sta. & Study area & Erosion points & Deposition points \\
\hline$A(\mathrm{ha})$ & $\mathrm{M}$ & 0.0 & 0.1 & 0.1 \\
& $\mathrm{Dt}$ & 0.3 & 0.4 & 0.5 \\
& Min & 0.0 & 2.1 & 0.0 \\
$\beta$ & Max & 6.7 & 5.0 & 4.1 \\
$\beta\left(^{\circ}\right)$ & $\mathrm{M}$ & 6.4 & 6.8 & 6.5 \\
& $\mathrm{Dt}$ & 1.8 & 1.5 & 1.9 \\
& Min & 0.0 & 3 & 2.4 \\
& Max & 14.8 & 9.3 & 11.9 \\
$K_{\text {sat }}(\mathrm{cm} / \mathrm{h})$ & $\mathrm{M}$ & 15.0 & 13.5 & 19.7 \\
& $\mathrm{Dt}$ & 10.0 & 10.5 & 10.7 \\
& Min & 2.0 & 3.9 & 3.3 \\
& Max & 44.0 & 40.5 & 42.9 \\
$\mathrm{BD}\left(\mathrm{g} / \mathrm{cm}^{3}\right)$ & $\mathrm{M}$ & 1.66 & 1.69 & 1.66 \\
& $\mathrm{Dt}$ & 0.09 & 0.09 & 0.07 \\
& Min & 1.11 & 1.41 & 1.49 \\
& Max & 1.90 & 1.89 & 1.86 \\
\hline
\end{tabular}

A case of spatial and temporal evaluation of erosion with RUSLE

E. V. Taguas et al.

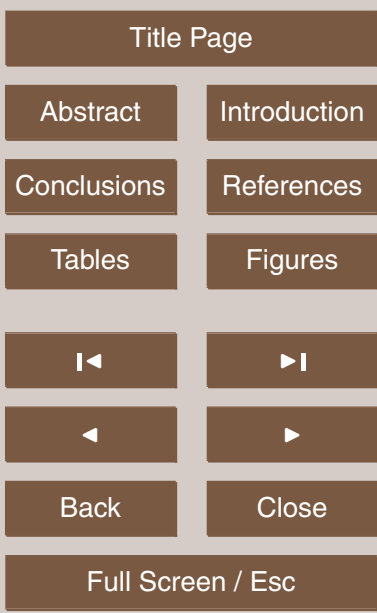

Printer-friendly Version

Interactive Discussion 


\section{A case of spatial and temporal evaluation of erosion with RUSLE}

Table 4. Summary of distribution function fittings for annual erosivities: root square mean error (RMSE), correlation coefficient between observed and predicted values $(R)$, value of discordance $(D)$ for Kolgorov-Smirnoff test's $\left(K_{5 \%}=\right.$ statistic $K$ for the test with a significance level of $5 \%$; $W=$ exceedance probability of Weibull's formula; $G=$ exceedance probability of Gringorten's formula).

\begin{tabular}{lcccc}
\hline & $\begin{array}{c}\text { Gumbel } \\
(\text { Form. } W)\end{array}$ & $\begin{array}{c}\text { Gumbel } \\
(\text { Form. G) }\end{array}$ & $\begin{array}{c}\text { Pearson TIII } \\
(\text { Form. } W)\end{array}$ & $\begin{array}{c}\text { Pearson TIII } \\
(\text { Form. G) }\end{array}$ \\
\hline RSME $\left(\mathrm{MJ} \mathrm{mm} \mathrm{ha}^{-1} \mathrm{~h}^{-1}\right)$ & 123.5 & 122.4 & 139.41 & 102.5 \\
$R$ & 0.97 & 0.97 & 0.98 & 0.98 \\
$D$ statistic $\left(K_{5 \%}=0.349\right)$ & 0.165 & 0.138 & 0.170 & 0.170 \\
\hline
\end{tabular}

Title Page

\section{Abstract}

Conclusions

Tables

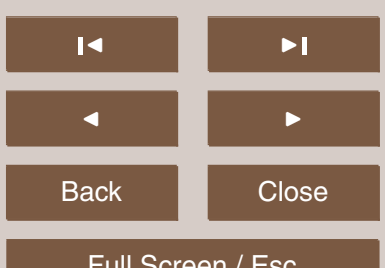

Full Screen / Esc

Printer-friendly Version

Interactive Discussion 


\section{A case of spatial and temporal evaluation of erosion with RUSLE}

Table 5. Values of $R$-factor for the return periods of 2,5, 10 and 15 years with the corresponding values of erosion derived from RUSLE in the catchment - mean, maximum, minimum and standard deviation; $F(R)=$ Accumulated probability of $R$-factor.

\begin{tabular}{lrcccc}
\hline $\begin{array}{l}T \\
\text { (years) }\end{array}$ & $\begin{array}{r}R \\
\left(\mathrm{MJ} \mathrm{mm} \mathrm{ha}^{-1} \mathrm{~h}^{-1}\right)\end{array}$ & $\begin{array}{c}\text { Mean Erosion } \\
\left(\mathrm{tha}^{-1} \mathrm{y}^{-1}\right)\end{array}$ & $\begin{array}{c}\text { Max Erosion } \\
\left(\mathrm{tha}^{-1} \mathrm{y}^{-1}\right)\end{array}$ & $\begin{array}{c}\text { Min Erosion } \\
\left(\mathrm{tha}^{-1} \mathrm{y}^{-1}\right)\end{array}$ & $\begin{array}{c}\text { Dv } \\
\left(\mathrm{tha}^{-1} \mathrm{y}-{ }^{-1}\right)\end{array}$ \\
\hline $2 ; F(R)=0.5$ & 473.5 & 2.0 & 19.2 & 0.0 & 2.7 \\
$5 ; F(R)=0.8$ & 952.4 & 4.1 & 38.5 & 0.0 & 5.3 \\
$10 ; F(R)=0.9$ & 1299.8 & 5.6 & 52.6 & 0.0 & 7.3 \\
$15 ; F(R)=0.93$ & 1501.2 & 6.5 & 60.7 & 0.0 & 8.4 \\
\hline
\end{tabular}

Title Page

Abstract

Introduction

Conclusions

References

Tables

Figures

14

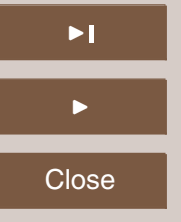

Back

Full Screen / Esc

Printer-friendly Version

Interactive Discussion 


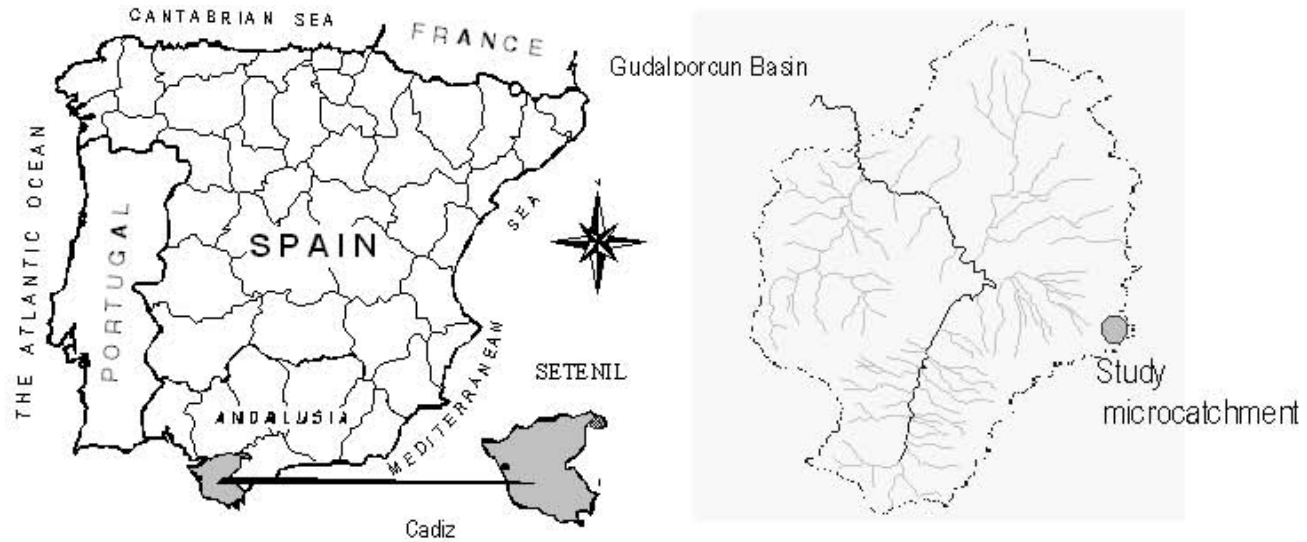

\section{SED}

2, 275-306, 2010

\section{A case of spatial and temporal evaluation of erosion with RUSLE}

E. V. Taguas et al.
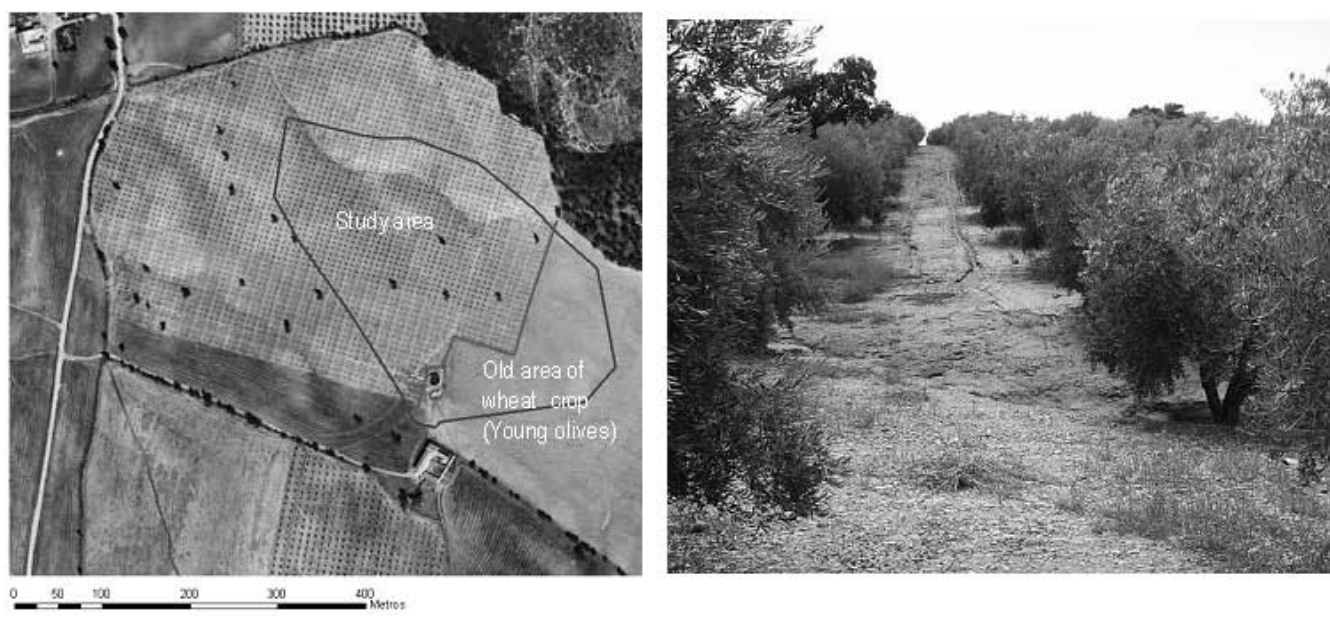

Fig. 1. Location of the microcatchment in Spain (top left) and situation of the microcatchment in the Gaudalporcun basin (top right). Limits of the catchment on the aerial ortophotography (bottom left) and view of hillslopes (bottom right).

Title Page

Abstract

Introduction

Conclusions

References

Tables

Figures

14

4

Back

Full Screen / Esc

Printer-friendly Version

Interactive Discussion
$>1$

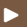

\section{lose}




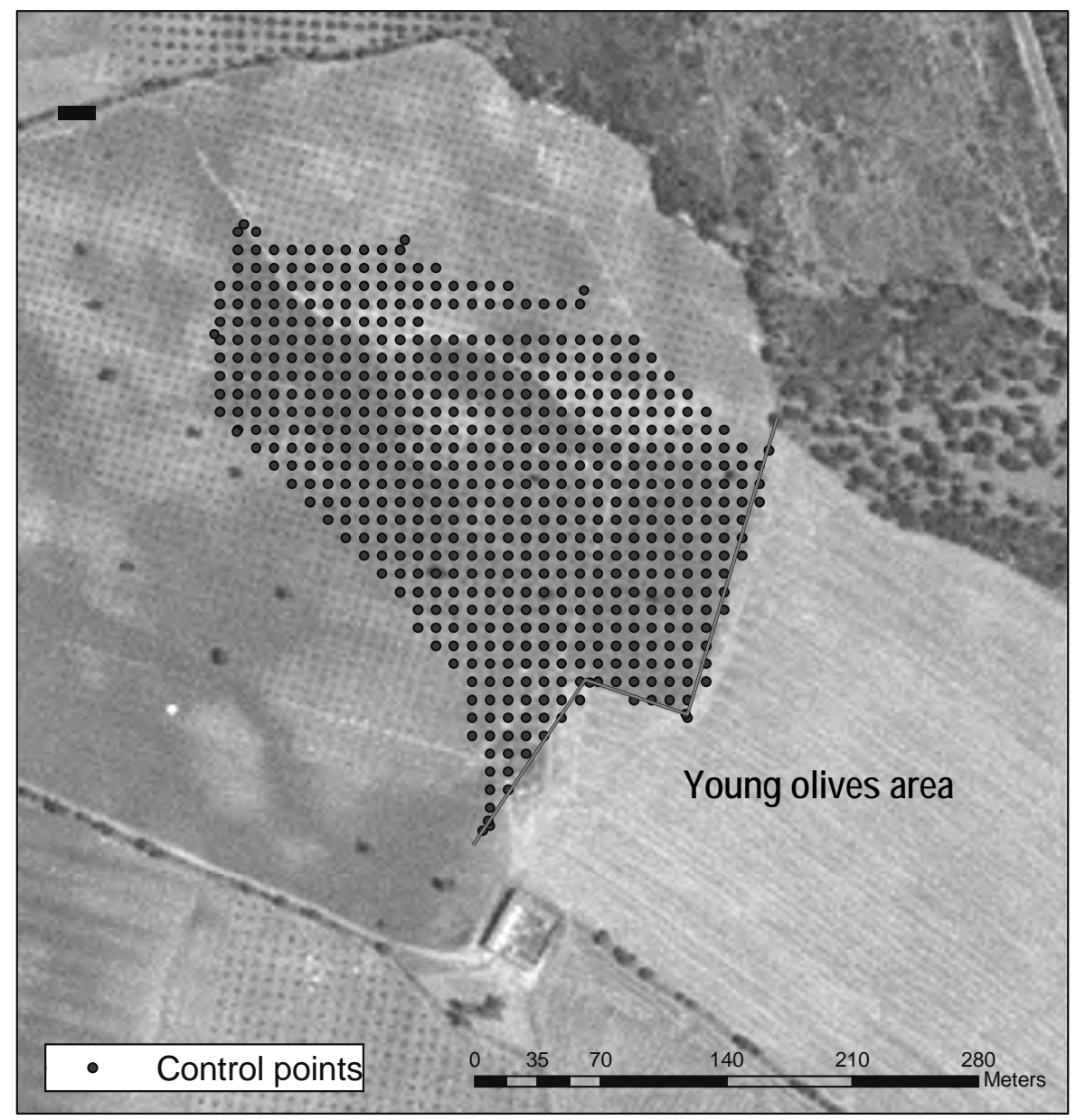

SED

$2,275-306,2010$

A case of spatial and temporal evaluation of erosion with RUSLE

E. V. Taguas et al.

Title Page

Abstract

Introduction

Conclusions

References

Tables

Figures

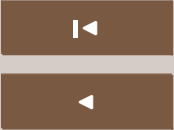

$\Delta$

Back

$\checkmark$

Close

Full Screen / Esc

Printer-friendly Version

Interactive Discussion

Fig. 2. Control points grid in the catchment, showing the study area with old olive trees where no tillage operations were applied for the study period. 


\section{SED}

$2,275-306,2010$

\section{A case of spatial and temporal evaluation of erosion with RUSLE}

E. V. Taguas et al.

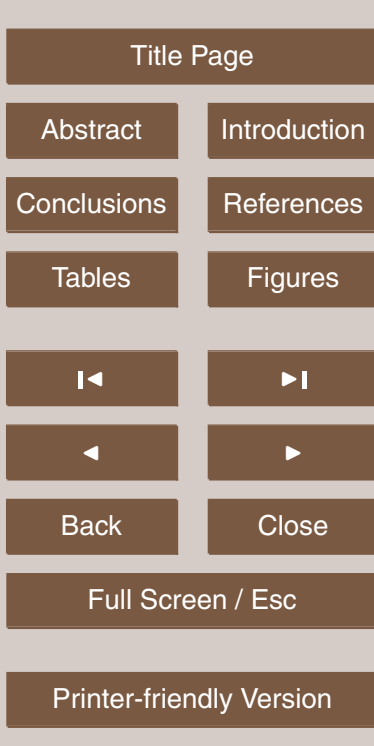

Interactive Discussion

Fig. 3. Distribution of RUSLE estimates for the period 2004-2005 with the evaluated erosion and depositon points (above). Distribution of RUSLE estimates for the period 2005-2006 (below).

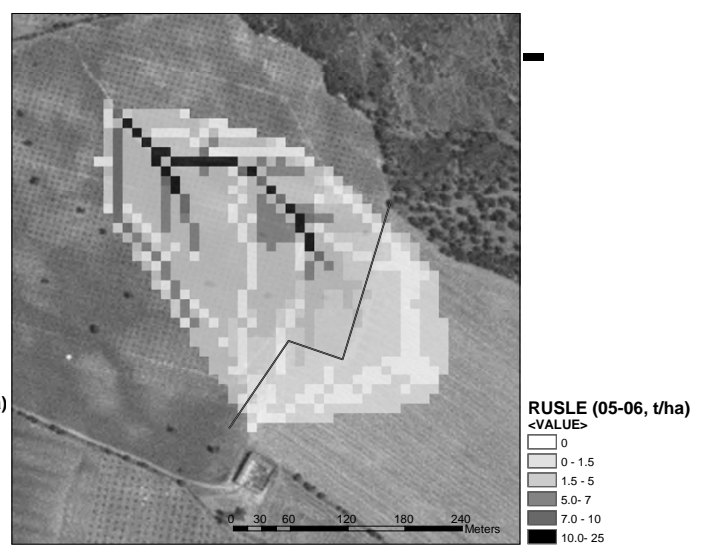



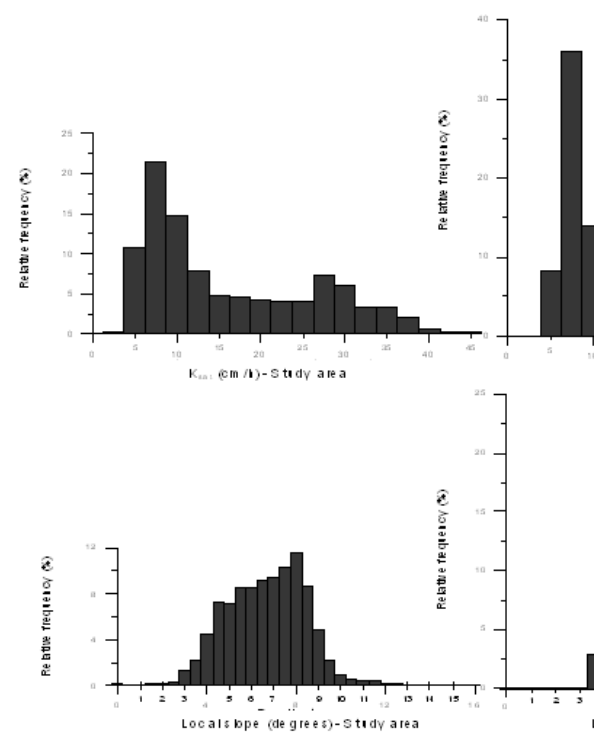

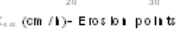

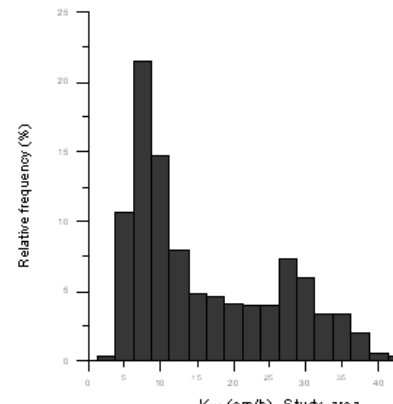

$K=1(\mathrm{~cm} / \mathrm{h}) \cdot$ Study area a)

SED

2, 275-306, 2010

\section{A case of spatial and} temporal evaluation of erosion with RUSLE

E. V. Taguas et al.

\section{Title Page}

Abstract

Conclusions

b)
Tables

14

4

Back
Introduction

References

Figures

- I

$>$

Close

\section{Full Screen / Esc}

Printer-friendly Version rated hydraulic conductivity ( $K_{\text {sat }}$, above) and the local slope values (below). (b) Histograms of the surface hydraulic saturated conductivity $\left(K_{\text {sat }}\right)$ values obtained in the study area and the deposition points.
Interactive Discussion

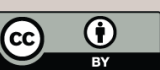




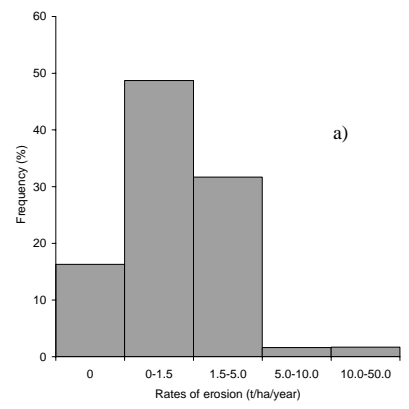

SED

2, 275-306, 2010

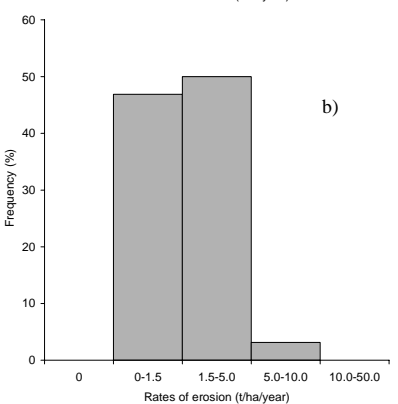

A case of spatial and temporal evaluation of erosion with RUSLE

E. V. Taguas et al.

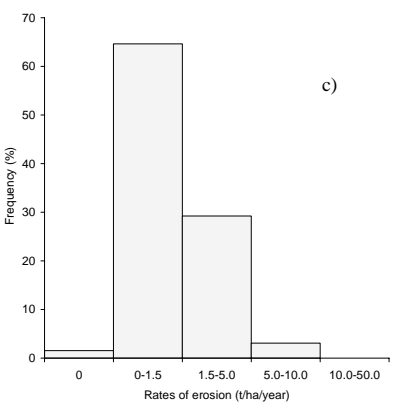

Title Page

Abstract

Conclusions

\section{Tables}

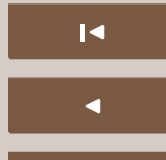

Back

Full Screen / Esc

Printer-friendly Version

Interactive Discussion

Fig. 5. (a) Hystogram of the RUSLE estimates in the study area; (b) Hystogram of the RUSLE estimates in the erosion points; (c) Hystogram of the RUSLE estimates in the deposition points. 

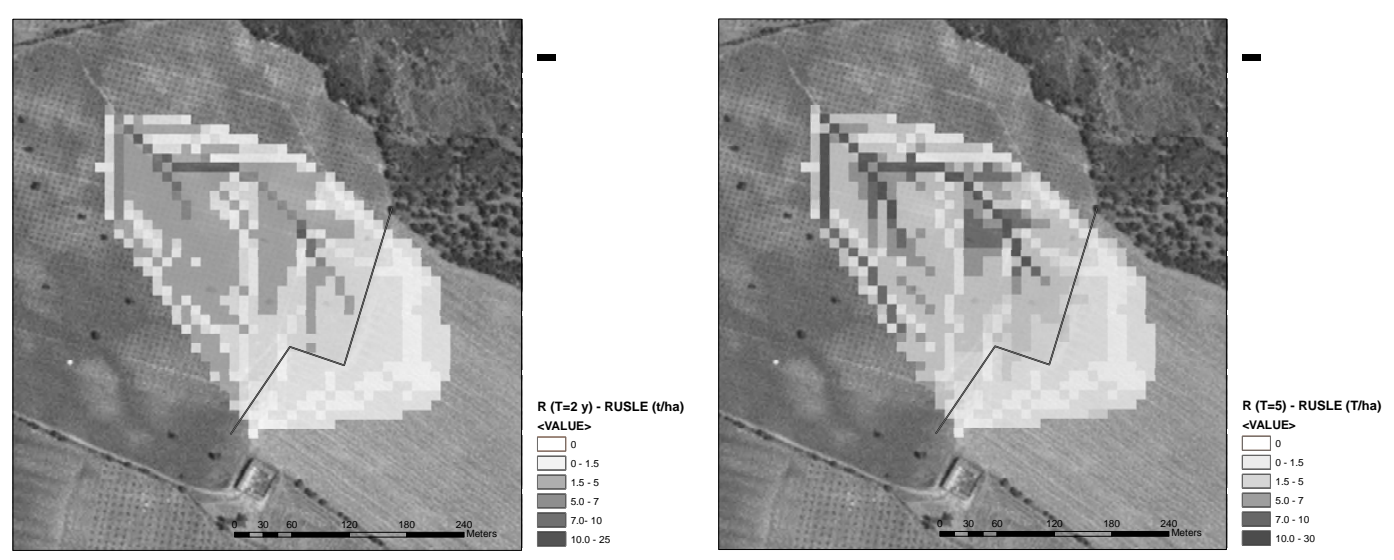

SED

$2,275-306,2010$

\section{A case of spatial and temporal evaluation of erosion with RUSLE}

E. V. Taguas et al.
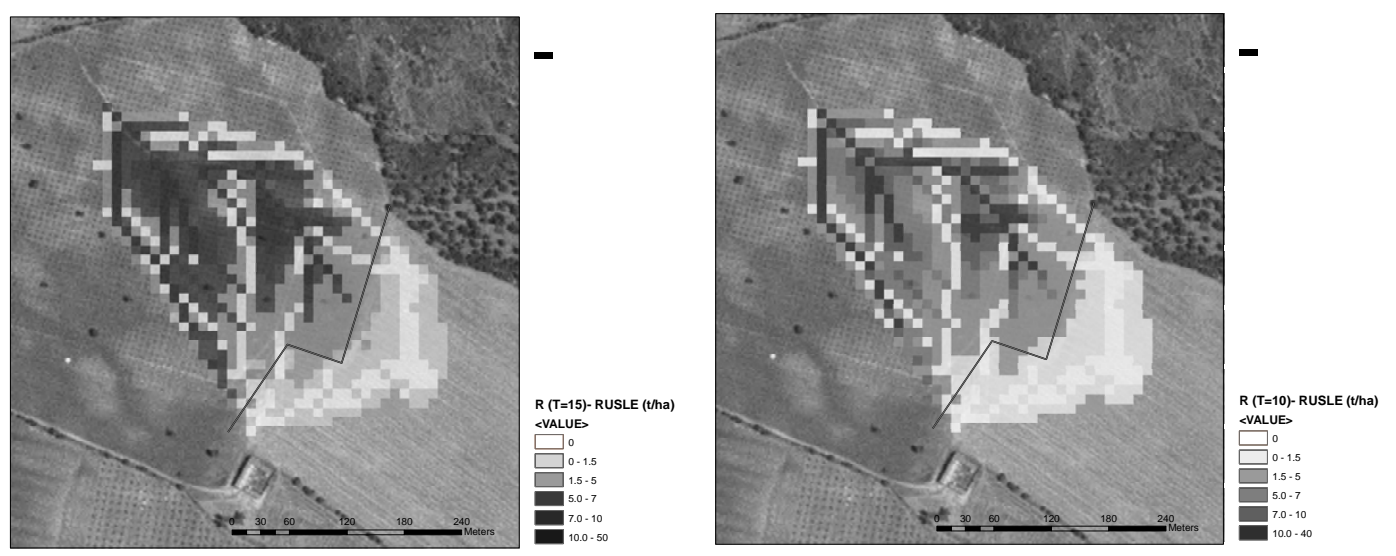

Fig. 6. RUSLE estimates calculated for the annual erosivities with return periods of $2,5,10$ and 15 years.

Printer-friendly Version

Interactive Discussion

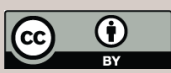

